\title{
Study of glycemic status, thyroid function and vitamin D3 level in children with $\beta$ thalassemia majorin a tertiary care center
}

\author{
Kumar Solanki D. ${ }^{1}$, Dewangan S. ${ }^{2 *}$, Sahu B. ${ }^{3}$ \\ DOI: https://doi.org/10.17511/ijpr.2020.i05.03 \\ ${ }^{1}$ Dhiraj Kumar Solanki, Associate Professor, Department of Paediatrics, Pt J.N.M. Medical College, Raipur, Chhattisgarh, India. \\ 2* Shashikant Dewangan, Assistant Professor, Department of Paediatrics, Pt J.N.M. Medical College, Raipur, Chhattisgarh, India. \\ 3 Bhoopendra Sahu, Resident, Department of Paediatrics, Pt J.N.M. Medical College, Raipur, Chhattisgarh, India.
}

Introduction: $\beta$ thalassemia has emerged as a huge public health problem worldwide. Thyroxine reserve is reduced in multitransfused thalassemia patientsanddiabetes can also be a considerable complication.Vitamin D3 deficiency is noted in thalassemia patients and is related to bone diseases. Aims and Objectives: Study of glycemic status, thyroid function, and vitamin D3 level in children with $\beta$ thalassemia major. Method: Socio-demographic information was collected by using the pretested and predesigned structured pro forma by interview technique. HbA1c level, vitamin D3 level,and thyroid function had been obtained from the lab.Result:In $89 \%$ of subjects TSH levels were normal with a mean value of 5.04.In $10.9 \%$ it was increased witha mean value of TSH being 6.67.VitaminD3 level in $2 \%$ children was below $20 \mathrm{ng} / \mathrm{ml}, 50.50 \%$ had between 21 to $29 \mathrm{ng} / \mathrm{ml}$ and $47.52 \%$ had between $30-60 \mathrm{ng} / \mathrm{ml}$. Vitamin D3 deficiency increased with a higher blood transfusion rate ( $p$-value 0.000 ). In $88.12 \%$ of the study, subjectsHbA1c was normal, $11.18 \%$ were inthe prediabetic range, and none of the subjects were diabetic as per HbA1C results. The mean value of $\mathrm{HbA1C}$ in normal children was $4.79 \%$ whereas in prediabetic children mean value of HbA1C was $6.13 \%$.Conclusion: In the present study multiple endocrine abnormalities were common in multi transfused thalassemia major patients. Prevalence of subclinical hypothyroidism and prediabetes increased with a higher blood transfusion rate and higher serum ferritin level. Prevalence of subclinical hypothyroidism and prediabetes increased with age ( $p$-value $<0.05$ ).

Keywords: $\beta$ thalassemia, HbA1c, TSH, Vitamin D3, Hypothyroidism, Prediabetes

\section{Corresponding Author}

Shashikant Dewangan, Assistant Professor Department of Paediatrics, Pt J.N.M. Medical College, Raipur, Chhattisgarh, India.

Email: drshashikantdewangan@gmail.com

\section{How to Cite this Article}

Solanki DK, Dewangan S, Sahu B. Study of glycemic status, thyroid function and vitamin D3 level in children with $\beta$ thalassemia majorin a tertiary care center. Pediatric Rev Int J Pediatr Res. 2020;7(5):204-209.

Available From

https://pediatrics.medresearch.in/index.php/ijpr/arti cle/view/597
To Browse

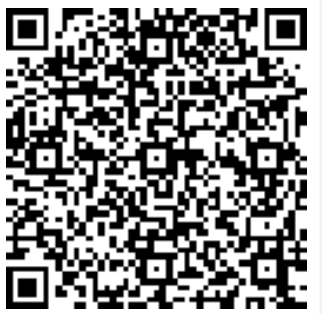

Manuscript Received 2020-05-27

Conflict of Interest No
Review Round 1 2020-06-08

Funding

Nil

$\begin{gathered}\text { Review Round } 2 \\ 2020-06-12\end{gathered}$
Ethical Approval
Yes

Review Round 2

Yes
Review Round 3

Plagiarism X-checke $6 \%$
Accepted 2020-06-17

Note

(C) 2020 by Dhiraj Kumar Solanki, Shashikant Dewangan, Bhoopendra Sahu and Published by Siddharth Health Research and Access Social Welfare Society. This is an Open Access article licensed under a Creative Commons Attribution 4.0 International License https://creativecommons.org/licenses/by/4.0/ unported [CC BY 4.0]. 


\section{Introduction}

Hemoglobinopathies are genetically determined inherited disorders of human hemoglobin, with significant morbidity worldwide. Among the hemoglobinopathies, there is the alpha and betathalassemia major, intermediate, and minor and sickle cell diseases [1]. Beta thalassemia major is an autosomal recessive hereditary anemia, and rapid erythrocyte breakdown, resulting in advanced heart failure and death in early childhood [2]. The combination of transfusion and chelation therapy has dramatically extended the life expectancy of thalassemia patients [3]. On the other hand, frequent blood transfusion in turn can lead to iron overload which may result in hypogonadism, diabetes mellitus, hypothyroidism, hypoparathyroidism, and other endocrine abnormalities [3]. Chhattisgarh is one of the growing stateswith one-third of its population belongs to scheduled tribes. Data shows that in 2012 Thalassemia carrier rate was $10.61 \%$, in 2013 it increased to $14.65 \%$ andin 2014 to $17.95 \%$ [4] Considering the above fact a cross-sectional study onglycemic status, thyroid function and vitamin D3 level in children with $\beta$ Thalassemia major was planned.

\section{Aims and Objectives}

Aims:Study of glycemic status, thyroid function, and vitamin D3 level in children with betathalassemia major.

\section{Objectives}

- To assess the thyroid function, HbA1c level,andvitamin D3 level.

- To correlate glycemicstatus, thyroid function test, vitamin D3 level, and serum ferritin level in thalassemia major patients.

\section{Material and Methods}

Design of study: This was a prospective crosssectional hospital-based observational study conducted between April 2018-March 2019.

Sample size: 101 thalassemic patients admitted during the study period in the Department of Pediatrics, Pt. J.N.M. Medical College, and Dr. B. R. Ambedkar Hospital Raipur (CG).

Inclusion criteria: Children age 2 years to 18 years having $\beta$ Thalassemia major whose parents gave the informed consent.
Exclusion criteria: Children <2years and $>18$ years of age with thalassemia and other hemoglobinopathies.

Method of data collection: Socio-demographic information was collected by usingpre-tested and predesigned structured pro forma by interview technique. Anthropometric measurement (heightandweight) was done using a calibrated standard technique. HbA1c, Serum Vitamin D3, TFT was obtained from laboratory records.

Data collection was divided into 4 parts

01. Interview

02. Anthropometric measurements

03. Clinical examination

04. Lab tests

\section{Interview}

- Basic identification detail and random selection of children.

- History and duration of illness.

- History and duration of blood transfusion.

\section{Anthropometric measurement}

\section{Clinical examination}

\section{Lab tests}

- Vitamin D3 Level

- Thyroid function test

- HbA1C level

- LFT/RFT

HbA1c is measured by using the HPLC method, serum vitamin D3, and thyroid function test is measured by electrochemiluminescence technique by Cobas e411.

\section{Statistical analysis}

- All relevant data entered into predesigned proforma was analyzed using Microsoft SPSS software for windows TM version 20.0, IBM TM Corp NY, and Microsoft excel TM, Microsoft Inc USA.

- Anthropometric data were analyzed using the WHO anthroplus software.

- Data are expressed as a percentage and mean \pm S.D. 
- A Chi-square test is used to analyze the significance of the difference between distributions of qualitative data.

- P-value $<0.05$ is considered as statistically significant.

Ethical approval: The study was conducted after taking ethical approval from the Institute's Ethical Committee.

\section{Result}

In the present study data of 101 Thalassemia major patients wereanalyzed,out of that 82 (81.19\%) were male and 19 (18.81\%)were female children. Age distribution data showed that $38 \%$ were below 5 years, $49 \%$ in between $5-10$ years, $13 \%$ were 11 15 years of age and 1 child was above 15 years of age.

Table-1: Age and sex distribution of study subjects.

\begin{tabular}{|l|l|l|}
\hline \multicolumn{1}{|c|}{ Age (Years) } & \multicolumn{1}{c|}{ Frequency } & \multicolumn{1}{c|}{ Percentage } \\
\hline$<5$ years & 38 & 37.62 \\
\hline $5-10$ years & 49 & 48.51 \\
\hline $11-15$ years & 13 & 12.87 \\
\hline$>15$ years & 1 & 0.99 \\
\hline Total & 101 & 100 \\
\hline Sex & Frequency & Percentage \\
\hline Male & 82 & 81.19 \\
\hline Female & 19 & 18.81 \\
\hline Total & 101 & 100 \\
\hline
\end{tabular}

The majority of the patients are from the age group $5-10$ years and the male to female ratio is $4.3: 1$.

Table-2: Age and sex-wise TSH level in study subjects.

\begin{tabular}{|l|l|l|l|l|}
\hline \multirow{2}{*}{ Age in years } & \multicolumn{2}{|c|}{ TSH Level } & \multirow{2}{*}{ Total } & \multirow{2}{*}{ p-value } \\
\cline { 2 - 3 } & Increased & Normal & & \\
\hline$<5$ years & $0(0 \%)$ & $38(100 \%)$ & $38(100 \%)$ & \multirow{2}{*}{0.000} \\
\hline $5-10$ years & $4(8.1 \%)$ & $45(91.1 \%)$ & $49(100 \%)$ & \\
\hline $11-15$ years & $6(46.15 \%)$ & $7(53.84 \%)$ & $13(100 \%)$ & \\
\hline$>15$ years & $1(100 \%)$ & $0(0 \%)$ & $1(100 \%)$ & \\
\hline Female & $2(10.52 \%)$ & $17(89.43 \%)$ & $19(100 \%)$ & \multirow{2}{*}{0.955} \\
\hline Male & $9(10.9 \%)$ & $73(89.02 \%)$ & $82(100 \%)$ & \\
\hline Total & $11(10.90 \%)$ & $90(89.10 \%)$ & $101(100 \%)$ & \\
\hline
\end{tabular}

Subclinical hypothyroidism prevalence increases with age( $p$-value 0.000).

Table-3: Age and sex-wise serum vitamin D3 level in study subjects.

\begin{tabular}{|l|l|l|l|l|l|}
\hline \multirow{2}{*}{ Age in years } & \multicolumn{3}{|c|}{ Serum vitamin D3 level } & \multirow{2}{*}{ Total } & \multirow{2}{*}{ p-value } \\
\cline { 2 - 4 } & Deficient & Insufficient & Sufficient & & \\
\hline$<5$ years & $0(0 \%)$ & $19(50 \%)$ & $19(50 \%)$ & $38(100 \%)$ & \multirow{2}{*}{0.644} \\
\hline $5-10$ years & $1(2.04 \%)$ & $26(53.06 \%)$ & $22(44.89 \%)$ & $49(100 \%)$ & \\
\hline $11-15$ years & $1(7.6 \%)$ & $6(46.15 \%)$ & $6(46.16 \%)$ & $13(100 \%)$ & \\
\hline$>15$ years & $0(0 \%)$ & $0(0 \%)$ & $1(100 \%)$ & $1(100 \%)$ & \\
\hline Female & $0(0 \%)$ & $12(63.15 \%)$ & $7(36.8 \%)$ & $19(100 \%)$ & \multirow{2}{*}{0.413} \\
\cline { 1 - 4 } Male & $2(2.4 \%)$ & $39(47.56 \%)$ & $41(50 \%)$ & $82(100 \%)$ & \\
\hline Total & $2(2 \%)$ & $51(50.50 \%)$ & $48(47.50 \%)$ & $101(100 \%)$ & \\
\hline
\end{tabular}

Vitamin D3 deficiency is more common in female patients.

Table-4: Age and sex-wise HbA1C level in study subjects.

\begin{tabular}{|l|l|l|l|l|}
\hline \multirow{2}{*}{ Age in years } & \multicolumn{2}{|c|}{ HbA1C } & \multirow{2}{*}{ Total } & \multirow{2}{*}{ p-value } \\
\cline { 2 - 3 } & Normal & Prediabetic & & \\
\hline$<5$ years & $36(94.7 \%)$ & $2(5.26 \%)$ & $38(100 \%)$ & \multirow{2}{*}{0.004} \\
\hline $5-10$ years & $44(89.7 \%)$ & $5(10.20 \%)$ & $49(100 \%)$ & \\
\hline $11-15$ years & $9(69.23 \%)$ & $4(30.76 \%)$ & $13(100 \%)$ & \\
\hline$>15$ years & $0(0 \%)$ & $1(100 \%)$ & $1(100 \%)$ & \\
\hline Female & $17(89.47 \%)$ & $2(10.52 \%)$ & $19(100 \%)$ & \multirow{2}{*}{0.839} \\
\hline Male & $72(87.80 \%)$ & $10(12.19 \%)$ & $82(100 \%)$ & \\
\hline Total & $89(88.10 \%)$ & $12(11.90 \%)$ & $101(100 \%)$ & \\
\hline
\end{tabular}

Prevalence of prediabetes increases with age ( $p$ value 0.004 ). Males having more prevalence.

Table-5: Relationship between blood transfusion rate, serum ferritin and serum vitamin D3 level in study subjects

\begin{tabular}{|c|c|c|c|c|c|}
\hline \multirow{2}{*}{$\begin{array}{c}\text { Blood transfusion } \\
\text { rate }\end{array}$} & \multicolumn{3}{|c|}{ Serum vitamin D3 level } & \multirow[t]{2}{*}{ Total } & \multirow{2}{*}{$\begin{array}{c}\mathrm{p}- \\
\text { value }\end{array}$} \\
\hline & Deficient & t Insufficient & Sufficient & & \\
\hline$<200 \mathrm{ml} /$ year & $0(0 \%)$ & $5(50 \%)$ & $5(50 \%)$ & $10(100 \%)$ & \multirow[t]{2}{*}{0.000} \\
\hline$>200 \mathrm{ml} /$ year & $\begin{array}{l}2 \\
(2.19 \%)\end{array}$ & $\mid \begin{array}{l}46 \\
(50.54 \%)\end{array}$ & $\begin{array}{l}43 \\
(47.25 \%)\end{array}$ & $91(100 \%)$ & \\
\hline Serum ferritin & Deficient & Insufficient & Sufficient & Total & \multirow[t]{5}{*}{0.921} \\
\hline$>2000 \mathrm{ng} / \mathrm{dl}$ & $\begin{array}{l}2 \\
(2.85 \%)\end{array}$ & $35(50 \%)$ & $\begin{array}{l}33 \\
(47.14 \%)\end{array}$ & $70(100 \%)$ & \\
\hline $1600-2000 \mathrm{ng} / \mathrm{dl}$ & $0(0 \%)$ & $\begin{array}{l}10 \\
(52.63 \%)\end{array}$ & $\begin{array}{l}9 \\
(47.36 \%)\end{array}$ & $19(100 \%)$ & \\
\hline $900-1600 \mathrm{ng} / \mathrm{dl}$ & $0(0 \%)$ & $6(50 \%)$ & $6(50 \%)$ & $12(100 \%)$ & \\
\hline Total & $2(2 \%)$ & $\begin{array}{l}51 \\
(50.5 \%)\end{array}$ & $\mid \begin{array}{l}48 \\
(47.5 \%)\end{array}$ & $\begin{array}{l}101 \\
(100 \%)\end{array}$ & \\
\hline
\end{tabular}

Vitamin D3 deficiency increases with a higher blood transfusion rate( $p$-value 0.000$)$.

Table-6: Relationship between blood transfusion rate, serum ferritin, and HbA1C level in study subjects.

\begin{tabular}{|l|l|l|l|l|}
\hline \multirow{2}{*}{ Blood transfusion rate } & \multicolumn{2}{|c|}{ HbA1C } & \multirow{2}{*}{ Total } & \multirow{2}{*}{-value } \\
\cline { 2 - 3 } & Normal & Prediabetic & & \\
\hline$<200 \mathrm{ml} /$ year & $10(100 \%)$ & $0(0 \%)$ & $10(100 \%)$ & 0.126 \\
\hline$>200 \mathrm{ml} /$ year & $79(86.81 \%)$ & $12(13.18 \%)$ & $91(100 \%)$ & \\
\hline
\end{tabular}




\begin{tabular}{|l|l|l|l|l|}
\hline Serum ferritin & Normal & Prediabetic & Total & P-value \\
\hline$>2000 \mathrm{ng} / \mathrm{dl}$ & $60(85.71 \%)$ & $10(14.28 \%)$ & $70(100 \%)$ & 0.515 \\
\cline { 1 - 4 } $1600-2000 \mathrm{ng} / \mathrm{dl}$ & $18(94.7 \%)$ & $1(5.2 \%)$ & $19(100 \%)$ & \\
\cline { 1 - 3 } $900-1600 \mathrm{ng} / \mathrm{dl}$ & $11(91.6 \%)$ & $1(8.3 \%)$ & $12(100 \%)$ & \\
\hline
\end{tabular}

Prevalence of prediabetes increases with a higher rate of blood transfusion and higher serum ferritin.

\begin{tabular}{|c|c|c|c|c|}
\hline \multirow{2}{*}{ Blood transfusion rate } & \multicolumn{2}{|c|}{ TSH level } & \multirow[t]{2}{*}{ Total } & \multirow[t]{2}{*}{ p-value } \\
\hline & Increased & Normal & & \\
\hline <200ml/year & $0(0 \%)$ & $10(100 \%)$ & $10(100 \%)$ & \multirow[t]{2}{*}{0.244} \\
\hline$>200 \mathrm{ml} /$ year & $11(12 \%)$ & $80(88 \%)$ & $91(100 \%)$ & \\
\hline Serum ferritin & Increased & Normal & Total & $p$-value \\
\hline$>2000 \mathrm{ng} / \mathrm{dl}$ & $11(15.7 \%)$ & $59(84.2 \%)$ & $70(100 \%)$ & \multirow[t]{4}{*}{0.065} \\
\hline $1600-2000$ ng/dl & $0(0 \%)$ & $19(100 \%)$ & $19(100 \%)$ & \\
\hline $900-1600 \mathrm{ng} / \mathrm{dl}$ & $0(0 \%)$ & $12(100 \%)$ & $12(100 \%)$ & \\
\hline Total & $11(10.8 \%)$ & $90(89.1 \%)$ & $101(100 \%)$ & \\
\hline
\end{tabular}

Shows increased TSH level with higher blood transfusion rate and higher serum ferritin values.TSH level in $89.10 \%$ subjects was in normal range whereas $10.90 \%$ of subjects were found to have subclinical hypothyroidism. For children with subclinical hypothyroidism, the mean value of TSH was $6.67 \mathrm{mIU} / \mathrm{ml}$. The mean value of TSH in all the children was 5.04 . $2 \%$ of children were having vitamin D3 level below $20 \mathrm{ng} / \mathrm{ml}, 50.50 \%$ had between 21 to $29 \mathrm{ng} / \mathrm{ml}$ and $47.52 \%$ had between $30-60 \mathrm{ng} / \mathrm{ml} .88 .12 \%$ of children had normal HbA1c, $11.18 \%$ was pre-diabetic and none of the children was diabetic as per $\mathrm{HbA} 1 \mathrm{C}$ results. The mean value of $\mathrm{HbA1C}$ in normal children was 4.79 and in prediabetic children mean value of HbA1C was 6.13. The mean $\mathrm{HbA1C}$ value in all the children was 4.95.

\section{Discussion}

In the present study, 101 children aged between 218 years were evaluated for their thyroid function. The male-female ratio was 4.3:1. THE mean TSH level of study subjects was $4.65 \pm 2.41 \mu \mathrm{IU} / \mathrm{ml}$. Prevalence of subclinical hypothyroidism was seen in $11 / 101(10.9 \%)$ study subjects and it was almost in equal proportion in malesand females (11\%and $10.5 \%$ respectively), there was no statistically significant association $(p=0.955)$ between sex and thyroid function of study subjects. The mean age of children with subclinical hypothyroidism was $11.6 \pm 3.6$ years and statistically significant association $(p=0.000)$ was found between age and subclinical hypothyroidism.
Malik SA et al (2010) reported 18 (25.7\%) of hypothyroid patients in beta-thalassemia patients with a mean age of $9.2 \pm 2.6$ years. [5] In contrast Eshragi P. et al (2011) reported mean age was $20.95 \pm 7.8$ years and $14.6 \%$ of patients were of hypothyroidism. [6]In a study by Hashemizadeh $\mathrm{H}$ et al (2012) Subclinical hypothyroidism was seen in $7 \%$ patients andthe mean age of diagnosis was 10.2 \pm 2.5 years [7]. In the present study all 11 children with hypothyroidism were transfused $>200 \mathrm{ml} / \mathrm{kg}$ year blood per year and serum ferritin levels were abnormally high (>2000 $\mathrm{ng} / \mathrm{dl}$ ) in all subclinical hypothyroid children. However, no statistically significant association $(p=0.065)$ was noted between serum ferritin and thyroid function.

Eshragip. et al (2011) examined the correlation between hypothyroidism and serum ferritin level, which was not significant $(p=0.584)$. [6]A similar study by Rindang $C$ et al (2011) examined that no relationship was found between the occurrence of hypothyroidism and blood transfusion levels $(P=0.481)$, elevated serum ferritin levels $(P=0.74)$. [8] In contradictory to our findings, Hashemizadeh $\mathrm{H}$ et al (2012)observed that the frequency of hypothyroidism was associated with increased serum ferritin levels $(p=0.037)[7]$.

HbA1C level in study subjects showed that 12 $(11.18 \%)$ children were pre-diabetic and none of the children was diabetic. The mean value of HbA1C in prediabetic children was 6.13 and in normal children mean value of HbA1c was 4.95. No statistically significant association $(p=0.839)$ was found between sex and HbA1C level of study subjects. The mean age of prediabetic children was $9.63 \pm 3.5$ years. Out of 12 pre-diabetic cases a maximum of $5(41.6 \%)$ were in $5-10$ years of age group followed by 4 (33.3\%)in $11-15$ years of age group, 2 were in less than 5 years and 1 was more than 15 years. Statistical significant association $(p=0.004)$ was found between age and HbA1C level of study subjects with increasing age there wasan increased risk of impaired glycemic status.

Tsilingiris D et al (2019) reported5.23\% mean HbA1c level in the group of $\beta$-thalassemia patients andnone of the study subjects was diabetic. This finding is similar to the present study[9]. Metwalley $\mathrm{KA}$ et al (2014) reported the prevalence of diabetes was $5 \%$ and impaired glucose tolerance test (IGT) was $8 \%$.[10] El-Samahy MH et al (2019) reported that $5 \%$ had $\mathrm{HbA} 1 \mathrm{C}$ readings within the diabetic range. [11] 
Li-Na He et al. (2019) in a metanalysis noted 6.54\% diabetes in patients with thalassemia major [12].

No statistically significant association $(p=0.126)$ was found between blood transfusion rate and HbA1C level of study subjects. Serum ferritin level was abnormally high ( $>1500 \mathrm{ng} / \mathrm{dl}$ ) in all 12 pre diabetic children and no statistically significant association $(p=0.515)$ was noted.

El-Hazmi MA et al (1994) reported moderate elevation of ferritin level in the majority of the betathalassemia major despite chelation (desferrioxamine) therapy [13]. El-Samahy MH et al (2019) noted that serum ferritin was the only independent variable related to elevated blood sugar levels[11]. Mashhadi, M. A. et al (2017) revealed that a significant association between beta-cell function on one hand and total units of blood transfusion and ferritin level on the other hand $(P=0.004, P=0.03$, respectively) [14].

In the present study, the mean value of vitamin D3 level in all the children was $29.72 \pm 4.60 \mathrm{ng} / \mathrm{ml}$. The mean age of children with low vitamin D3 levels was $6.4 \pm 3.56$ years and no statically significant association $(p=0.644)$ was found between age and low vitamin D3 level.

Fahim, F. M. et al (2013) reported that $49 \%$ of patients had short stature. $47 \%$ were underweight [15]. Ahmed Zeeshan et al. (2019) examined serum calcium and vitamin D status in multi transfused $\beta$ thalassemia major children. The mean values of serum vitamin $D(13.12 \pm 2.9)$ were significantly lower inpatients as compared to that of standard population values, the difference in each being statistically significant [16].

In the present study, a statistically significant association $(p=0.000)$ was found between higher blood transfusion rate and low vitamin D3 level. Serum ferritin level was also abnormally high $(>1600 \mathrm{ng} / \mathrm{dl})$ in all 53children with low vitamin D3 level. However, no statistically significant association $(p=0.921)$ was noted between serum ferritin levelsand low vitamin D3 levels.

Fahim, F. M. et al (2013) reported that children with beta-thalassemia major have delayed growth and metabolic abnormalities may be due to iron overload and poor nutritional support [15]. Gombar $S$ et al (2018) reported that the level of serum ferritin was significantly high and vitamin $D$ was significantly low $(p$-value $<0.001)$ in multi transfused thalassemic children [17].

\section{Conclusion}

In the present study, multiple endocrine abnormalities were common in multi transfused thalassemia major patients. Prevalence of subclinical hypothyroidism and prediabetes increases withincreasing age. There is a positive correlation between increased iron overload with endocrine abnormalities.

\section{What does the study add to the existing knowledge?}

No information is available for thalassemic endocrine abnormality in patients of Chhattisgarh.Subclinical hypothyroidism, prediabetic status, and vitamin D3 insufficiencywere found in multi transfused $\beta$ thalassemia patients of Chhattisgarh.

\section{Author's contributions}

Dr. Solanki D.K. conceived, conceptualized, supervised the study, and finalized the manuscript.

Dr. Dewangan S. helped in protocol writing, conceptualization, data analysis, and finalized the manuscript.

Dr. Sahu B. wrote the protocol, recruited patients, analyzed the data, and prepared manuscript. The final manuscript was approved by all authors.

\section{Reference}

01. Old J, Harteveld CL, Traeger-Synodinos J, Petrou M, Angastiniotis M, Galanello R. Haematological Methods, In Prevention of Thalassaemias and Other Haemoglobin Disorders- Volume 2Laboratory Protocols [Internet]. Thalassaemia International Federation. 2nd edition 2012. [Crossref]

02. Weatherall DJ, Clegg JB. Inherited haemoglobin disorders- An increasing global health problem. Bull World Health Organ. 2001;79(8)704-712. [Crossref]

03. De VS, Roos M, Gasser T, Fortini M, Raiola G, Galati MC. Impact of long-term iron chelation therapy on growth and endocrine functions in thalassaemia. J Pediatr Endocrinol Metab. $2006 ; 19(4) 471-480$.

[Crossref] 
04. S T, SN R. Thalassemia prevalence in the state of Chhattisgarh- A short-review of the Literature. J Blood Disord Med. 2018;3;5-7. [Crossref]

05. Malik SA, Syed S, Ahmed N. Frequency of hypothyroidism in patients of b-thalassemia. J Pak Med Assoc. 2010;60(1)17-20.

[Crossref]

06. Eshragi P, Tamaddoni A, Zarifi K, Mohammadhasani A, Aminzadeh M. Thyroid function in major thalassemia patients- Is it related to height and chelation therapy?. Casp J Intern Med. 2011;2(1)189-193.

[Crossref]

07. Hashemizadeh H, Noori R. Assessment of Hypothyroidism in Children with BetaThalassemia Major in North Eastern Iran. Iran J Pediatic Hematol Oncol. 2012;2(3)123-127. [Crossref]

08. Rindang C, Batubara JRL, Amalia P, Satari H. Some aspects of thyroid dysfunction in thalassemia major patients with severe iron overload. Paediatr Indones. 2011;51(2)66-72.

doi: $\quad 10.14238 / p i 51.2 .2011 .66-72 \quad$ [Crossref]

09. Tsilingiris D, Makrilakis K, Voskaridou E, Pagkrati S, Dalamaga M, Liatis S. Effect of heterozygous beta thalassemia on HbA1c levels in individuals without diabetes mellitus- A cross sectional study. Clin Chim Acta. 2019;494;132-137.

doi: $\quad 10.1016 /$ j.cca.2019.03.1611 [Crossref]

10. Metwalley K, El-Saied AR. Glucose homeostasis in Egyptian children and adolescents with $\beta$ Thalassemia major- Relationship to oxidative stress. Indian J Endocrinol Metab. 2014;18(3)333-339. doi: $10.4103 / 2230-8210.131169$ [Crossref]

11. El-Samahy MH, Tantawy AA, Adly AA, Abdelmaksoud $A A$, Ismail $E A$, Salah NY. Evaluation of continuous glucose monitoring system for detection of alterations in glucose homeostasis in pediatric patients with $\beta$ thalassemia major. Pediatr Diabetes. 2019;20(1)65-72.

doi: 10.1111/pedi.12793 [Crossref]
12. He LN, Chen $W$, Yang $Y, X i e ~ Y J$, Xiong $Z Y$, Chen $D Y$, et al. Elevated Prevalence of Abnormal Glucose Metabolism and Other Endocrine Disorders in Patients with $\beta$-Thalassemia MajorA Meta-Analysis. Biomed Res Int. 2019. doi: 10.1155/2019/6573497 [Crossref]

13. El-Hazmi MA, Al-Swailem A, Al-Fawaz I, Warsey AS, Al-Swailem $A$, et al. Diabetes mellitus in children suffering from $\beta$-thalassaemia. J Trop Pediatr. 1994;40(5)261-266.

doi: 10.1093/tropej/40.5.261 [Crossref]

14. Mashhadi MA, Sepehri Z, Heidari Z, Kaykhaei MA, Sargazi A, Kohan F, et al. A cross-sectional study of glycemic status and zinc level in patients with Beta-Thalassemia major. Int J Hematol Stem Cell Res. 2017;11(4)273-280. [Crossref]

15. Fahim FM, Saad K, Askar EA, Eldin EN, Thabet AF. Growth parameters and vitamin $D$ status in children with thalassemia major in upper Egypt. Int J Hematol Stem Cell Res. 2013;7(4)10-14. [Crossref]

16. Ahmed Z, P Kausar MS, Sinah D. Study of serum calcium, phosphorus and vitamin $D$ status in multi transfused $\beta$-thalassemia major children and adolescents of Jharkhand, India. Int J Contemp Pediatr. 2019;6(2)598.

doi: 10.18203/2349-3291.ijcp20190694 [Crossref]

17. Gombar S, Parihar K, Choudhary M. Comparative study of serum ferritin and vitamin $D$ in thalassemia patients with healthy controls. Int J Res Med Sci. 2018;6(2)693.

doi: $10.18203 / 2320-6012 . i j r m s 20180322$ [Crossref] 